\title{
Study on the relationship between Word Preference and Stock Returns under the background of intelligent information
}

\author{
Yunhong $\mathrm{Li}^{1{ }^{1, *}}$ \\ ${ }^{1}$ School of Economics and management, Chongqing University of Arts and Sciences, 319 Honghe Avenue, China
}

\begin{abstract}
Based on intelligent informatics, this study examines whether corporate names with implications of luck and taboo have different effects on firm value using a sample of Chinese IPO firms. With the help of the gre en s ervice s ystem, i t $\mathrm{c}$ an provi des investment decisions for the consumers. We $\mathrm{f}$ ind that a fter controlling for other influencing factors, $\mathrm{P} / \mathrm{E}$ ratios are positively a ssociated with lucky names but have a slightly negative re lationship with taboo names. Similarly, CARs are positively correlated to lucky names but negatively with taboo names. The results also indicate that China's IPO firms with taboo names have higher first-day returns, but drop faster than do other firms, indicating that these firms experience lower pricing when getting listed. Our findings highlight the economically meaningful role of firms' names in the process of going public.
\end{abstract}

\section{Introduction}

A $n$ umber of $r$ esearchers i nvestigate $\mathrm{f}$ actors a ffecting investment behaviors $t$ hrough ps ychological theories such a s cognitive bias. T versky and Kahneman (1974), and Kahneman a nd T versky (1979a, b) e mploy th e prospect theory based on the psychological theoreies to offer new explanations to the behaviors that are used to be viewed as irrational or abnormal in the stock market. Thus, how ps ychological $r$ easons a ffect stock $r$ eturns have attracted wide attention in academics.

In c apital market, the studies focus on the effect of name $\mathrm{c}$ hange on the s tock $\mathrm{r}$ eturns. The financial press discusses $\mathrm{w}$ hether $\mathrm{c}$ orporate na me $\mathrm{c}$ hanges $\mathrm{r}$ esult $\mathrm{i} \mathrm{n}$ permanent value creation for firms. Analysts c laim that investors prefer cer tain $t$ ypes of names, and $t$ hat $t$ he value of a c ompany's na me should be reflected in the stock price.

This study investigates whether the "good" and "bad" names cr eating the firm values. While past $s$ tudies a re devoted to the effect of name changes, they focus on less whether the g ood and bad names per s e have the real effect on corporate values. We examine the performance about of price-to-earnings ratio ( $\mathrm{P} / \mathrm{E}$ ratio) and first-day to 12 -month c umulative abnormal returns initial first of after i nitial $\mathrm{p}$ ublic o ffering (IP O) firms $\mathrm{w}$ ith $\mathrm{b}$ etween lucky a nd $t$ aboo names firms. Using a s ample of 866 domestic I POs d uring December 1990 t o D ecember 2009, we $f$ ind $t$ hat $f$ irms' $n$ ames play a s tatistically significant a nd e conomically meaningful $r$ ole i $n t$ he process of going public

\section{Lucky and Taboo Names in Chinese Culture}

This s ection classifies the Chinese companies' into two groups on the basis of their names, where one group has Lucky words in the names and the other has the Taboo words. The L ucky and $\mathrm{T}$ aboo words a re based on the following c riteria. If the firms' names c ontain "Gold", "Silver", "Fortune", "Smooth", “Prosperity", "Dragon" and "Phoenix", these firms a re classified a s the L ucky firms. On the o ther $h$ and, if the firms' names c ontain "Four, West, Valley, Empty, Bear", they are classified as the Taboo firms.

\section{Econometric Model}

We i nvestigate p ost-performance of L ucky a nd T aboo firms a fter their I POs. We e xamine whether the postperformance will be the same or not a cross theses two types of firms. Two post-performance measures are the average $s$ tock $\mathrm{p}$ rice/earnings ratio $(\mathrm{P} / \mathrm{E}) \mathrm{a}$ nd $\mathrm{t}$ he abnormal returns (AR).

The a verage $\mathrm{P} / \mathrm{E} \mathrm{r}$ atio is based on $\mathrm{t}$ he $\mathrm{f}$ ollowing formula:

$$
(P / E)_{t}=\frac{1}{n} \sum_{i=1}^{n} P / E_{i, t}
$$

where $\mathrm{P}$ is the stock price, $\mathrm{E}$ is the earnings in the year, $\mathrm{n}$ is the number of firms in the group. Next,

\footnotetext{
* Corresponding author: 1yh-83906@163.com
} 


$$
A R_{i, t}=R_{i, t}-R_{M, t}
$$

where subscripts $i$ and $t$ denote ith firm at time $t, A R$ is the abnormal returns, $\mathrm{R}$ is the rate of return, and $\mathrm{RM}, \mathrm{t}$ is the market return, which is proxied by the return of ShangHai stock index. The event date is the date of IPO. Our event window $(0,12)$ for e ach corporate is the 12 months after its IPO, where event window 0 is the first day after IPO (i.e., initial day return) and 1 to 12 are the months after IPOs.

Our regression model is

$$
\begin{aligned}
& P / E_{i, t=s}=\alpha_{0}+\alpha_{1} \text { Lucky }_{i, t=s}+\alpha_{2} \text { Taboo }_{i, t=s} \\
& +\alpha_{3} D_{\text {State }, i, t=s}+\alpha_{4} \text { Rate }_{i, t=s}+\alpha_{5} \text { LnCap }_{i, t=s} \\
& +\alpha_{6} \text { Trade }_{i, t=s}+\alpha_{7} \text { Return }_{i, t=s}+\alpha_{8} D_{\text {ind }, i, t=s} \\
& +\alpha_{9} D_{\text {FirstDay }} \times \text { Return }_{M, t=s}+\varepsilon_{k, i, t}
\end{aligned}
$$

$$
\begin{aligned}
& A R_{i, t=s}=\beta_{0}+\beta_{1} \text { Lucky }_{i, t=s}+\beta_{2} \text { Taboo }_{i, t=s} \\
& \quad+\beta_{3} D_{\text {Statei } i t=s}+\beta_{4} \text { LnCap }_{i, t=s}+\beta_{5} \text { Turnover }_{i, t=s} \\
& \quad+\beta_{6} P / E_{i, t=s}+\beta_{7} D_{\text {ind }, i, t=s}+\beta_{8} D_{\text {FirstDay }} P_{0, i} \\
& \quad+\beta_{9} D_{\text {FirstDay }_{\text {Dhe }}} \text { Share }_{i, t=s}+\varepsilon_{i, t=s}
\end{aligned}
$$

$\mathrm{s}=0$ (first day) $1,2,3, \ldots, 12$ (months)

where s ubscripts $\mathrm{i}$ is the $\mathrm{i}$ th $\mathrm{firm}, \mathrm{N}$ is the $\mathrm{n}$ umber of firms, and $\mathrm{s}$ d enotes the nu mber of pe riods a fter IPO. The 0 and 1 12 have the same meanings in event study, namely, when $s=0$, it is the first day after IPO (i.e., initial day return) and when $s=1,2, \ldots, 12$, it is the $\mathrm{s}$ th month after IPO. The cross sectional model is employed.

Lucky a nd $\mathrm{T}$ aboo are two d ummy va riables, which are equal to unities if the firms ' $n$ ames contain L ucky and Taboo words, respectively and 0 otherwise.

The selection of other explanatory variables for $\mathrm{P} / \mathrm{E}$ is as follows.

Rate is the benchmark interest rate; is the logarithm of the firm's capital; $T$ rade de notes the trading ratio, which is the percentage of shares that can be traded in the $\mathrm{m}$ arket; Return $\mathrm{i} \mathrm{s}$ t he $\mathrm{i}$ ndividual $\mathrm{s}$ tock $\mathrm{r}$ eturns; ReturnM is the market stock return. DState is a dummy variable, which is equal to unity if the firms are stateowned and 0 otherwise; is the industry dummy variable, which is equal to unity if the firm belongs to a strategic emerging industry and 0 otherwise.

The s election of explanatory $\mathrm{v}$ ariables for $\mathrm{AR}$ is a s follows. Turnover is the turnover rate; $\mathrm{P} / \mathrm{E}$ is the priceto-earnings ratio us ed t o $\mathrm{c}$ ontrol $\mathrm{f}$ or $\mathrm{t}$ he higher $\mathrm{s}$ tock returns as a result of higher $\mathrm{P} / \mathrm{E}$ ratio given by investors; DFirstDay i s the d ummy variable, which i s e qual to unity if it is the first day a fter IPO and zero otherwise. P0 is the offering price to c ontrol for the price effects (Ritter, 1 991). $\mathrm{S}$ hare $\mathrm{s}$ tands fo $\mathrm{r} t$ he $\mathrm{p}$ roportion of $\mathrm{t}$ he largest shareholder.

\section{Data and Empirical Results}

\subsection{Data Description}

Our IPOs a re collected from 1 isted $\mathrm{f}$ irms on $\mathrm{S}$ hanghai Stock $E$ xchange e xcluding $f$ inancial institutions. $T$ he total number of 1 isted firms is 866 . A mong them, there are 66 a nd $34 \mathrm{~L}$ ucky a nd Taboo firms, respectively; whereas th ere a re 800 and 832 of the non-Lucky a nd non-Taboo firms, respectively. The sample period covers 1990:12 to $2009: 12$.

\subsection{Empirical Results}

Table 1 and Table 2 present the regression results when $\mathrm{P} / \mathrm{E}$ ratio is used as the dependent variable using the IPO sample on the first trading day $(\mathrm{t}=0)$ and the periods of 1 , $2, \ldots, 12 \mathrm{~m}$ onths a fter IP O. The weighted least s quares (WLS) $r$ egressions a re $\mathrm{c}$ arried out. When $\mathrm{P} / \mathrm{E}$ i s t he dependent variable, coefficients of Lucky is significantly positive in 10 out of the 13 testing pe riods, suggesting that $f$ irms with 1 ucky names $t$ end $t o$ have $h$ igher $P / E$ ratios immediately after IPO. By contrast, the coefficient of $\mathrm{T}$ aboo i s significantly $\mathrm{n}$ egative i $\mathrm{n} t$ he $\mathrm{f}$ irst $\mathrm{t}$ hree months, demonstrating that IPO firms with taboo words are more 1 ikely $t$ o have 1 ower $\mathrm{P} / \mathrm{E} \mathrm{r}$ atios i $\mathrm{n} t$ he $\mathrm{f}$ irst several months a fter getting $\mathrm{l}$ isted. Note $\mathrm{t}$ hat $\mathrm{t}$ he disadvantage of Taboo name does not last for a long time

\begin{tabular}{|c|c|c|c|c|c|c|c|}
\hline \multirow[b]{2}{*}{ Variable } & \multicolumn{7}{|c|}{ Month } \\
\hline & 0 & 1 & 2 & 3 & 4 & 5 & 6 \\
\hline \multirow[t]{2}{*}{ Constant } & $139.347^{* * *}$ & $166.128 * * *$ & $129.472 * * *$ & $125.039 * * *$ & $119.345^{* * *}$ & $122.31 * * *$ & $128.294 * * *$ \\
\hline & $(15.374)$ & $(20.701)$ & $(16.966)$ & $(15.938)$ & $(15.456)$ & $(19.12)$ & $(20.371)$ \\
\hline \multirow[t]{2}{*}{ Lucky } & 1.192 & 2.64 & $4.795^{* *}$ & $4.234 * *$ & $5.302^{* * *}$ & $4.458 * * *$ & $8.332 * * *$ \\
\hline & $(0.763)$ & $(1.516)$ & $(2.328)$ & $(2.258)$ & $(3.657)$ & $(2.79)$ & $(7.753)$ \\
\hline Taboo & $-8.694 * * *$ & $-6.841^{* *}$ & $-3.68^{* * *}$ & -0.453 & -1.952 & 2.647 & $3.424 *$ \\
\hline & $(-7.105)$ & $(-2.681)$ & $(-3.257)$ & $(-0.282)$ & $(-1.279)$ & (1.437) & (1.724) \\
\hline
\end{tabular}
since their $\mathrm{P} / \mathrm{E}$ ratios are similar with others after the first two months. Hence, given the s ame e arnings, investors pay higher price for firms w ith lucky na mes but lower price for firms with taboo names. Thus, corporate names are influential on investors' assessment on the valuation, and investors' $p$ reference for lucky names s eems to be longer than that for taboo names.

Table 1. Regression Analysis of P/E Ratio(1) 


\begin{tabular}{|c|c|c|c|c|c|c|c|}
\hline$D_{\text {State }}$ & $-2.948 * * *$ & $-2.332 * *$ & $-2.033 *$ & $-3.746 * * *$ & $-5.704 * * *$ & $-5.251 * * *$ & $-4.958 * * *$ \\
\hline & $(-2.69)$ & $(-2.395)$ & $(-1.896)$ & $(-3.435)$ & $(-6.203)$ & $(-5.069)$ & $(-5.003)$ \\
\hline \multirow[t]{2}{*}{ LnCap } & $-4.653 * * *$ & $-5.307 * * *$ & $-3.782 * * *$ & $-3.536 * * *$ & $-3.171 * * *$ & $-3.465 * * *$ & $-3.832 * * *$ \\
\hline & $(-10.637)$ & $(-13.344)$ & $(-10.278)$ & $(-9.206)$ & $(-8.17)$ & $(-11.095)$ & $(-12.722)$ \\
\hline \multirow[t]{2}{*}{$D_{\text {Ind }}$} & $4.078^{* * *}$ & 1.211 & $1.468 *$ & $2.095^{* *}$ & $3.46^{* * *}$ & $2.003 *$ & $3.49 * * *$ \\
\hline & $(4.058)$ & $(1.253)$ & $(1.808)$ & $(2.262)$ & $(3.801)$ & $(1.75)$ & $(3.255)$ \\
\hline \multirow[t]{2}{*}{ Trade } & $0.072 * *$ & $-0.451 * * *$ & $-0.234 * * *$ & $-0.195 * * *$ & $-0.187 * * *$ & $-0.106 * *$ & -0.062 \\
\hline & $(2.463)$ & $(-10.351)$ & $(-5.436)$ & $(-4.309)$ & $(-4.2)$ & $(-2.406)$ & $(-1.623)$ \\
\hline \multirow[t]{2}{*}{ Return } & $0.018 * * *$ & $0.28 * * *$ & $0.284 * * *$ & $0.279 * * *$ & $0.185 * * *$ & $0.162 * * *$ & $0.045^{* *}$ \\
\hline & $(9.544)$ & (10.877) & $(10.526)$ & $(9.765)$ & $(6.139)$ & $(6.462)$ & $(2.125)$ \\
\hline \multirow[t]{2}{*}{ Rate } & $-1.578 * * *$ & $-1.111 * * *$ & $-1.194 * * *$ & $-1.281 * * *$ & $-1.344 * * *$ & $-1.293 * * *$ & $-1.424 * * *$ \\
\hline & $(-11.565)$ & $(-8.675)$ & $(-9.073)$ & $(-10.055)$ & $(-10.172)$ & $(-9.204)$ & $(-10.208)$ \\
\hline \multirow[t]{2}{*}{ Return $_{M}$} & 0.178 & & & & & & \\
\hline & $(0.992)$ & & & & & & \\
\hline$R^{2}$ & 0.89 & 0.90 & 0.99 & 0.87 & 0.93 & 0.86 & 0.92 \\
\hline Nobs & 829 & 830 & 825 & 826 & 826 & 828 & 827 \\
\hline
\end{tabular}

Note: Those tables present the weighted least squares (WLS) regression results of $\mathrm{P} / \mathrm{E}$ ratio with the weight $\mathrm{w}=$, where the standard error is estimated using ordinal least squares (OLS) of each regression. Month 0 denotes the first trading day. For the definitions of each $v$ ariable, s ee the text. $t$-values a re provided in pa rentheses. $*, * *$ and $* * *$ de note significance at $10 \%, 5 \%$ a nd $1 \% 1$ evels, respectively.

Table 2. Regression Analysis of P/E Ratio(2)

\begin{tabular}{|c|c|c|c|c|c|c|}
\hline \multirow[b]{2}{*}{ Variable } & \multicolumn{6}{|c|}{ Month } \\
\hline & 7 & 8 & 9 & 10 & 11 & 12 \\
\hline \multirow[t]{2}{*}{ Constant } & $138.828 * * *$ & $138.966^{* * *}$ & $144.143 * * *$ & $158.27 * * *$ & $150.984 * * *$ & $160.834 * * *$ \\
\hline & $(27.245)$ & $(28.36)$ & $(22.308)$ & $(25.917)$ & $(24.492)$ & $(26.946)$ \\
\hline \multirow[t]{2}{*}{ Lucky } & $7.116^{* * *}$ & $3.484 * * *$ & $3.79 * * *$ & 2 & 1.983 & $2.65 * *$ \\
\hline & $(6.203)$ & $(4.171)$ & $(3.126)$ & (1.249) & $(1.436)$ & (1.998) \\
\hline \multirow[t]{2}{*}{ Taboo } & -1.248 & -0.481 & -0.964 & -1.299 & 1.043 & 0.879 \\
\hline & $(-0.616)$ & $(-0.38)$ & $(-0.366)$ & $(-0.479)$ & $(0.548)$ & $(0.664)$ \\
\hline \multirow[t]{2}{*}{$D_{\text {State }}$} & $-5.544 * * *$ & $-4.805 * * *$ & $-2.292 * *$ & $-3.049 * * *$ & $-3.268 * * *$ & $-3.706^{* * *}$ \\
\hline & $(-6.312)$ & $(-5.581)$ & $(-2.437)$ & $(-3.265)$ & $(-3.171)$ & $(-3.455)$ \\
\hline \multirow[t]{2}{*}{ LnCap } & $-4.099 * * *$ & $-4.132 * * *$ & $-4.462 * * *$ & $-4.986^{* * *}$ & $-4.6 * * *$ & $-4.927 * * *$ \\
\hline & $(-17.05)$ & $(-16.709)$ & $(-14.475)$ & $(-16.686)$ & $(-15.47)$ & $(-17.485)$ \\
\hline \multirow[t]{2}{*}{$D_{\text {Ind }}$} & $4.044 * * *$ & $3.303 * * *$ & $3.741 * * *$ & $2.551 * * *$ & 1.069 & -0.29 \\
\hline & $(3.89)$ & $(4.244)$ & $(5.706)$ & $(3.43)$ & $(1.326)$ & $(-0.332)$ \\
\hline \multirow[t]{2}{*}{ Trade } & $-0.159 * * *$ & $-0.123 * * *$ & $-0.145 * * *$ & $-0.213 * * *$ & $-0.166 * * *$ & $-0.256 * * *$ \\
\hline & $(-4.096)$ & $(-3.57)$ & $(-3.084)$ & $(-5.895)$ & $(-4.027)$ & $(-5.97)$ \\
\hline \multirow[t]{2}{*}{ Return } & $0.228 * * *$ & -0.012 & $0.134 * * *$ & $0.242 * * *$ & $0.051^{* *}$ & $0.181 * * *$ \\
\hline & $(12.401)$ & $(-0.693)$ & $(5.802)$ & $(8.853)$ & $(2.246)$ & $(9.588)$ \\
\hline \multirow[t]{2}{*}{ Rate } & $-1.591 * * *$ & $-1.562 * * *$ & $-1.674 * * *$ & $-1.728 * * *$ & $-1.823 * * *$ & $-1.729 * * *$ \\
\hline & $(-12.745)$ & $(-15.803)$ & $(-14.967)$ & $(-16.324)$ & $(-15.318)$ & $(-15.185)$ \\
\hline \multicolumn{7}{|l|}{ Return $_{M}$} \\
\hline$R^{2}$ & 0.92 & 0.95 & 0.95 & 0.95 & 0.92 & 0.91 \\
\hline Nobs & 825 & 821 & 821 & 821 & 820 & 824 \\
\hline
\end{tabular}

Note: Those tables present the weighted least squares (WLS) regression results of $\mathrm{P} / \mathrm{E}$ ratio with the weight $\mathrm{w}=$, where the standard error is estimated using ordinal least squares (OLS) of each regression. Month 0 denotes the first trading day. For the definitions of each v ariable, s ee the text. t-values a re p rovided in pa rentheses. $*, * *$ and $* * *$ de note significance at $10 \%, 5 \%$ a nd $1 \% 1$ evels, respectively. 
Table 3 and Table 4 using C AR a s the dependent variable. $\mathrm{T}$ he $\mathrm{c}$ oefficients of $\mathrm{L}$ ucky $\mathrm{i}$ s significantly positive in five out of the 13 testing periods, suggesting that lucky-named firms exhibit moderately higher stock returns a fter $\mathrm{t}$ heir IPO. $\mathrm{T}$ he $\mathrm{c}$ oefficients of $\mathrm{T}$ aboo a re significantly p ositive in our first two C AR r egressions; however, it is s ignificantly negative in five out of the other $11 \mathrm{t}$ esting pe riods. Thus, IPO $\mathrm{f}$ irms $\mathrm{w}$ ith taboo names have s lightly $l$ ower CARs e xcept $f$ or $t$ he $f$ irst month. Investors prefer lucky to n on-lucky na mes for several months i mmediately af ter the I PO, an d do $n$ ot like Taboo names relative to non-Taboo names after the "honey-moon" $m$ onth. A ccordingly, i nvestors a re attracted by lucky names.

Table 3. Regression Analysis of CAR(1)

\begin{tabular}{|c|c|c|c|c|c|c|c|}
\hline \multirow[b]{2}{*}{ Variable } & \multicolumn{7}{|c|}{ Month } \\
\hline & 0 & 1 & 2 & 3 & 4 & 5 & 6 \\
\hline \multirow[t]{2}{*}{ Constant } & $22.544 * * *$ & $-42.259 * * *$ & $-34.288 * * *$ & $-8.696^{* * *}$ & $3.798 * * *$ & $-7.018 * * *$ & -0.607 \\
\hline & $(44.481)$ & $(-11.386)$ & $(-14.074)$ & $(-6.625)$ & (4.449) & $(-3.228)$ & $(-0.402)$ \\
\hline \multirow[t]{2}{*}{ Lucky } & 0.161 & $3.844 * * *$ & $2.548 * * *$ & -0.281 & 0.146 & $0.900 * * *$ & $1.045^{* * *}$ \\
\hline & (1.377) & $(6.241)$ & $(3.481)$ & $(-0.654)$ & $(0.285)$ & $(2.786)$ & (2.609) \\
\hline \multirow[t]{2}{*}{ Taboo } & $0.564 * *$ & $9.682 * * *$ & $-2.120 * * *$ & -0.543 & $-3.115^{* * *}$ & -0.679 & $-2.411 * * *$ \\
\hline & (2.3) & (14.494) & $(-3.538)$ & $(-0.868)$ & $(-5.319)$ & $(-1.265)$ & $(-6.779)$ \\
\hline \multirow[t]{2}{*}{$D_{\text {State }}$} & $0.277 * * *$ & $1.784 * * *$ & $-0.988 * * *$ & $0.900 * * *$ & -0.224 & $-0.487 *$ & 0.117 \\
\hline & $(5.408)$ & (3.817) & $(-2.772)$ & $(3.245)$ & $(-0.694)$ & $(-1.667)$ & $(0.483)$ \\
\hline \multirow[t]{2}{*}{ LnCap } & $-1.027 * * *$ & $1.733 * * *$ & $1.344 * * *$ & 0.046 & $-0.433 * * *$ & $0.202^{*}$ & -0.086 \\
\hline & $(-39.789)$ & $(9.091)$ & (10.877) & $(0.732)$ & $(-10.444)$ & $(1.826)$ & $(-1.145)$ \\
\hline \multirow[t]{2}{*}{$D_{\text {Ind }}$} & $-0.173 * * *$ & -0.671 & $0.843 * * *$ & $1.909 * * *$ & -0.173 & -0.360 & $0.782 * * *$ \\
\hline & $(-3.501)$ & $(-1.356)$ & (2.593) & $(9.452)$ & $(-0.566)$ & $(-1.575)$ & (4.103) \\
\hline \multirow[t]{2}{*}{ Turnover } & $-0.021 * * *$ & $0.024 * * *$ & $0.057 * * *$ & $0.080 * * *$ & $0.056 * * *$ & $0.032 * * *$ & $0.033 * * *$ \\
\hline & $(-17.301)$ & $(10.205)$ & $(21.714)$ & $(28.774)$ & $(38.422)$ & (11.016) & (18.139) \\
\hline \multirow[t]{2}{*}{$P / E$} & $0.025 * * *$ & $0.050 * * *$ & $0.063 * * *$ & $0.041 * * *$ & $0.026 * * *$ & $0.042 * * *$ & $0.012 * * *$ \\
\hline & (27.799) & $(10.061)$ & (10.307) & $(11.722)$ & (8.082) & (11.961) & (3.533) \\
\hline \multirow[t]{2}{*}{$D_{\text {FirstDay }} P_{0}$} & $-0.097 * * *$ & & & & & & \\
\hline & $(-22.831)$ & & & & & & \\
\hline \multirow[t]{2}{*}{$D_{\text {FirstDayShare }}$} & $-0.391 * * *$ & & & & & & \\
\hline & $(-6.11)$ & & & & & & \\
\hline$R^{2}$ & 0.89 & 0.40 & 0.49 & 0.56 & 0.70 & 0.29 & 0.37 \\
\hline Nobs & 829 & 830 & 825 & 826 & 826 & 828 & 827 \\
\hline
\end{tabular}

Note: Those tables present the weighted least squares (WLS) regression results of $\mathrm{P} / \mathrm{E}$ ratio with the weight $\mathrm{w}=$, where the standard error is estimated using ordinal least squares (OLS) of e ach regression. Month 0 denotes the first trading day. For the definitions of each v ariable, s ee the text. t-values a re provided in pa rentheses. ${ }^{*}, * *$ and $* * *$ de note significance at $10 \%, 5 \%$ a nd $1 \% 1$ evels, respectively.

Table4. Regression Analysis of CAR(2)

\begin{tabular}{|l|c|c|c|c|c|c|}
\hline & \multicolumn{7}{|c|}{ Month } \\
\hline Variable & 7 & 8 & 9 & 10 & \multicolumn{1}{c|}{11} \\
\hline Constant & -2.807 & $-12.921 * * *$ & $-2.732^{*}$ & $-11.463 * * *$ & $-5.531 * * *$ & 3.033 \\
\hline & $(-1.397)$ & $(-7.22)$ & $(-1.799)$ & $(-7.053)$ & $(-2.851)$ & $(1.587)$ \\
\hline Lucky & $-1.500^{* * *}$ & $-1.823 * * *$ & -0.574 & $-0.824 * *$ & $0.983 * * *$ & 0.310 \\
\hline & $(-3.271)$ & $(-3.429)$ & $(-1.173)$ & $(-2.068)$ & $(2.202)$ & $(0.668)$ \\
\hline Taboo & -0.821 & 0.666 & $2.594 * * *$ & $-3.809 * * *$ & $-0.798 * * *$ & 0.251 \\
\hline & $(-1.455)$ & $(1.149)$ & $(3.785)$ & $(-6.436)$ & $(-4.727)$ & $(0.406)$ \\
\hline DState & $-1.456 * * *$ & $-0.565 * *$ & $0.785 * * *$ & -0.130 & $-0.523 * * *$ & $1.844 * * *$ \\
\hline
\end{tabular}




\begin{tabular}{|l|c|c|c|c|c|c|}
\hline & $(-5.87)$ & $(-2.043)$ & $(3.684)$ & $(-0.592)$ & $(-2.575)$ & $(7.212)$ \\
\hline LnCap & 0.083 & $0.504 * * *$ & -0.039 & $0.378^{* * *}$ & 0.122 & $-0.430^{* * *}$ \\
\hline$D_{\text {Ind }}$ & $(0.819)$ & $(5.37)$ & $(-0.521)$ & $(4.525)$ & $(1.242)$ & $(-4.279)$ \\
\hline & $1.030^{* * *}$ & 0.306 & $-0.610^{* *}$ & -0.317 & 0.259 & $-1.129 * * *$ \\
\hline Turnover & $(3.661)$ & $(1.213)$ & $(-2.338)$ & $(-1.348)$ & $(1.077)$ & $(-4.775)$ \\
\hline & $0.030 * * *$ & $0.027 * * *$ & $0.023 * * *$ & $0.038^{* * *}$ & $0.059 * * *$ & $0.071 * * *$ \\
\hline P/E & $(9.674)$ & $(16.427)$ & $(8.78)$ & $(11.4)$ & $(16.456)$ & $(20.273)$ \\
\hline & $0.021 * * *$ & $0.042 * * *$ & $0.031 * * *$ & $0.065^{* * *}$ & $0.026 * * *$ & $0.038^{* * *}$ \\
\hline$D_{\text {FirstDay }} P_{0}$ & $(8.732)$ & $(13.506)$ & $(8.198)$ & $(19.716)$ & $(6.348)$ & $(10.008)$ \\
\hline & & & & & & \\
\hline$D_{\text {FirstDayShare }}$ & & & & & & \\
\hline & & & & & & \\
\hline$R^{2}$ & 0.28 & 0.68 & 0.21 & 0.41 & 0.44 & 0.41 \\
\hline Nobs & 825 & 821 & 821 & 821 & & 824 \\
\hline
\end{tabular}

Note: Those tables present the weighted least squares (WLS) regression results of $\mathrm{P} / \mathrm{E}$ ratio with the weight $\mathrm{w}=$, where the standard error is estimated using ordinal least squares (OLS) of each regression. Month 0 denotes the first trading day. For the definitions of each $v$ ariable, s ee the text. t-values a re provided in pa rentheses. $*, * *$ and $* * *$ de note significance at $10 \%, 5 \%$ a nd $1 \% 1$ evels, respectively.

\section{Conclusion}

This paper i nvestigates whether c orporate na mes $\mathrm{w}$ ith implications of luck and taboo have different effects on firm value. We address this i ssue by s tudying the $\mathrm{P} / \mathrm{E}$ ratios and CARs of China's IPO firms during the period of 19 90-2009. T he results s how that IP O fi rms with lucky names exhibit s lightly higher post-IPO $\mathrm{P} / \mathrm{E}$ ratios over the 12 months and higher initial returns on the first trading day, whereas $t$ hose $\mathrm{w}$ ith $\mathrm{t}$ aboo names ha ve significantly lower $\mathrm{P} / \mathrm{E}$ ratios. After controlling for other influencing factors, $\mathrm{P} / \mathrm{E}$ ratios a re positively a ssociated with 1 ucky names b ut have a slightly ne gative relationship $w$ ith $t$ aboo names. $\mathrm{S}$ imilarly, CA Rs a re positively correlated to lucky names but negatively with taboo names. The results also indicate that China's IPO firms with taboo names have higher first-day returns, but drop $f$ aster $t$ han do ot her firms, i ndicating t hat $t$ hese firms experience lower pricing when getting listed.

\section{Acknowledgments}

This w ork was Supported by S cientific a nd Technological Research $\mathrm{P}$ rogram of Chongqing Municipal E ducation C ommission (KJ1601131) and Social Science Fund of Chongqing (2018QNGL36).

\section{References}

1. K. Anderson, , C. Brooks, Decomposing the PriceEarnings R atio, J ournal of A sset Management 6, 14(2005)

2. D.Basu, Investment pe rformance of c ommon s tock in relation to their price-earnings ratio: a test of the efficient $m$ arket hy pothesis. Journal of Finance 32, 20(1977)

3. L. Han, Y.H. Tang, T he i nfluence of s tate-owned shareholder o $\mathrm{nl}$ isting c orporation. Technoeconomics \& $\mathrm{M}$ anagement $\mathrm{R}$ esearch 3, 3(2002)

4. S. J. Li, Analysis of the influential Factors Affecting IPO $\mathrm{i}$ nitial $\mathrm{r}$ eturns $\mathrm{i} \mathrm{nc}$ hina, $\mathrm{S}$ cience and Management 3, 4(2010)

5. K. Rydqvist 1997.IPO und erpricing a s ta X-efficient compensation. J ournal of B anking a nd $\mathrm{F}$ inance 21, 19(1997) 